\title{
Hubungan Sanitasi Lingkungan Rumah Tangga Dengan Kejadian Stunting Pada Anak Balita Di Puskesmas Wonomulyo Kabupaten polewali Mandar Tahun 2019
}

\author{
Yuliani Soeracmad ${ }^{1}$, Muhammad Ikhtiar ${ }^{2}$ Agus Bintara $\mathrm{S}^{3}$ \\ 1,2 Program Pasca Sarjana, prodi Kesehatan Lingkungan, Universitas Muslim Indonesia, \\ Sulawesi Selatan. \\ E-mail: yulianisoerachmad70@gmail.com
}

\section{Relationship of Household Environmental Sanitation with Stunting Occurrence in Toddler Children in Wonomulyo Health Center, Wonomulyo District, Polewali Mandar Regency, West Sulawesi in 2019}

\begin{abstract}
Stunting is a condition of failure to thrive in children under five due to malnutrition occurring since the baby is in the womb and in the early period after the baby is 2 years old. The aim is to analyze the Risk Factors for Household Environmental Sanitation. This type of research is Observational Analytic with Case Control approach. The results of this study explain that washing hands with soap in running water is 2 times the risk of stunting with a $\mathrm{p}$ value of $0.000>0.05$ meaning that statistically has a significant effect between washing hands in running water using soap with the occurrence of stunting. While household waste management is at risk of 2 stunting incidents with a value of $p$ $0,000>0.05$ meaning that statistically has a significant influence between securing household waste with a stunting event and drinking water and household food management 2 times at risk of stunting with indigo 1,000>0.05 which statistically does not have a significant influence between drinking water and household food management on the occurrence of stunting. Then securing the sewerage water 2 times has the risk of stunting with a $\mathrm{p}$ value of $0,000>0.05$ meaning that statistically has a significant effect between the management of household sewerage with stunting. Washing hands in running water with soap, securing household waste, securing household sewage has an effect on stunting, while drinking water and household food management have nothing to do with events stuntin $\mathrm{g}$ in children under five
\end{abstract}

Keywords: Stunting, Toddler Environmental Sanitation

\begin{abstract}
Abstrak
Stunting adalah kondisi gagal tumbuh pada anak balita yang di akibatkan kekurangan gizi terjadi sejak bayi dalam kandungan dan pada masa awal setelah bayi berusia 2 tahun. Tujuannya untuk menganalisis Faktor Risiko Sanitasi Lingkungan Rumah Tangga. Jenis penelitian yang digunakan adalah Observasional Analitik dengan pendekatan Case Control. Hasil penelitian ini menjelaskan bahwa Cuci tangan pakai sabun di air mengalir merupakan 2 kali beresiko terjadinya stuntingdengan nilai $\mathrm{p} 0,000>0,05$ artinya secara statistik mempunyai pengaruh yang bermakna antara cuci tangan di air mengalir pakai sabun dengan kejadian stunting. Sedangkan pengamana sampah rumah tangga beresiko 2 kali kejadian stunting dengan nilai $\mathrm{p} 0,000>0,05$ artinya secara statistik mempunyai
\end{abstract}


pengaruh yang bermakna antara pengamanan sampah rumah tangga dengan kejadian stunting.dan pengelolaan air minum dan makanan rumah tangga 2 kali beresiko terjadinya stunting dengan nila $\mathrm{p} 1,000>0,05$ dimana secara statistika tidak memiliki pengaruh yang bermakna antara pengelolaan air minum dan makanan rumah tangga terhadap kejadian stunting.Kemudian pengamanan saluran pembuangan air limbah $2 \mathrm{kali}$ beresiko terjadinya stunting dengan nilai p 0,000>0,05 artinya secara statistik mempunyai pengaruh yang bermakna antara pengelolaan saluran pembuangan air limbah rumah tangga dengan kejadian stunting.. cuci tangan di air mengalir pakai sabun,pengamanan sampah rumah tangga ,pengamanan saluran pembuangan air limbah rumah tangga berpengaruh terhadap kejadian stunting sedangkan pengelolaan air minum dan makanan rumah tangga tidak ada hubungan dengan kejadian stunting pada anak balita.

Kata kunci: Stunting,Sanitasi Lingkungan Balita

\section{PENDAHULUAN}

Secara global, sekitar 162 juta anak balita mengalami kependekan. Afrika sub Sahara dan Asia Selatan rumah untuk tiga perempat anak pendek dunia. Data menunjukkan bahwa $40 \%$ balita di Afrika sub sahara mengalami stunting sedangkan di Asia Selatan tercatat sebesar $39 \%$ (WHO) Stunting Infographic. Saat Ini Indonesia masih dihadapkan pada masalah stunting ( malgizi kronis) yang cukup serius . Total ada 9 juta atau lebih dari sepertiga jumlah balita di Indonesia Menderita Stunting.

Status gizi balita marupakan salah satu cerminan keadaan gizi masyarakat luas.Stunting atau stunted growth atau nutritional stunting menurut WHO artinya adalah penurunan laju pertumbuhan panjang badan atau tinggi badan dalam keseluruhan proses pertumbuhan perkembangan yang ditentukan dengan nilai height for age atau tinggi badan menurut dibawah dari minus 2 standar deviasi (WHO,2014).

Kementerian Kesehatan Republik Indonesia memberikan perhatian yang sangat besar terhadap pencegahan dan penanganan masalah gizi di Indonesia, dengan salah satu fokus utama masalah stunting atau kerdil. Berbagai upaya telah dilaksanakan, baik di level Pusat maupun di level daerah. 
Kebijakan-kebijakan yang memperkuat pelaksanaan intervensi spesifik dan sensitive telah diterbitkan oleh Pemerintah, diantara adalah peraturan residen No. 38 tahun 2017 tentang kebijakan strategis pangan dan gizi (KSPG) kebijakan startegis ini kemudian diterjemahkan kedalam rencana aksi nasional pangan gizi (RAN-PG) dan rencana aksi daerah pangan dan gizi (RAD-PG). Dalam perpres no. 38 tahun 2017, pemerintah menggaris bawahi pentingnya koordinasi serta peran serta lintas sector seperti Pemerintah Pusat, Pemerintah Daerah, dan berbagai pemangku kepentingan.

Kejadian balita pendek atau biasa disebut dengan stunting merupakan salah satu masalah gizi yang dialami oleh balita di dunia saat ini. Pada tahun 2017 22,2\% atau sekitar 150,8 juta balita di dunia mengalami stunting. Pada tahun 2017 lebih dari setengah balita stunting di dunia berasal dari Asia 55\% sedangkan lebih dari pertiganya 39\% tinggal di Afrika.Dari 83,6 juta balita stunting di Asia. Proporsi terbanyak berasal dari Asia Selatan 58,7\% dan proporsi paling sedikit di Asia Tengan $0,9 \%$ (jhont child motnutation etimotes 2018).

Saat ini masih banyak orang tua yang tidak menyadari masalah stunting pada anak karena seorang anak yang stunting umumnya tidak terlihat seperti anak yang bermasalah,dan hal inii seperti di anggap umum dikalangan orang awam,bila dari orang tua yang pendek maka wajar bila anak -anaknya juga pendek. 1dari 3 balita di Indonesia atau $37,2 \%$ nya mengalamii stunting, dan hal ini yang menjadi tantangan besar tidak hanya bagi pemerintah namun juga semua sektor yang terkait (Rikesdas 2013).

Tahun 2018 proporsi status gizi buruk dan gizi kurang pada balita di provinsi Sulawesi barat sebanyak 29,5\% proporsi status gizi sangat pendek dan pendek pada balita untuk wilayah provinsii Sulawesi Barat yaitu sebanyak 40,6\% dan menjadi angka tertinggi kedua setelah Nusa tenggara timur 45,6\%. (Riskesdas 2018)

Pada dasarnya status gizi anak dapat di pengaruhi oleh faktor langsung, tidak langsung, dan akar masalah . Faktor langsung yang berhubungan dengan stunting yaitu berupa asupan makanan dan status kesehatan. Asupan energi menunjukan hubungan yang signifikan terhadap kejadian stunting .

Begitupun selanjutnya, pola pengasuhan, pelayanan kesehatan dan lingkungan rumah tangga sebagai faktor tidak langsung akar masalah yang meliputi 
wilayah tempat tinggal dan status ekonomi memberikan hubungan dengan buruknya status gizi anak.

Risksdas (Riset Kesehatan Dasar) 2013 mencatat prevalensi stunting nasional mencapai $37,2 \%$ terdiri dari $18,0 \%$ sangat pendek dan 19,2\% pendek, meningkat daritahun $2010(35,6 \%)$ dan 2007 (36,8\%). Artinya, pertumbuhan tak maksimal diderita oleh sekitar 8 juta anak indonesia, atau satu dari tiga anak indonesia . prevalensi stunting di indonesia lebih tinggi dari pada negaranegara lain di asia tenggara, seperti Myanmar |(35\%), Vietnam (23\%) dan Thailand (16\%) (MCA Indonesia 2014 dalam Yusdarif 2017).

Masalah kesehatan masyarakat dianggap berat bila prevalensinya sebesar 30-39\% dari serius bila prevalensinyaa $\geq 40 \%$ (WHO,2010). Dari acuan ini , angka prevalensi stunting nasional indonesia tergolong dalam kategori berat. Sedangkan berdasarkan Rskesdas 2013, masalah stunting di 14 provinsi di indonesia tergolong kategori berat, dan sebanyak 15 provinsi lainnya tergolong kategori serius. Tercatat 20 provinsi yang angka prevalensinya diatas prevalensi nasional. Salah satunya adalah provinsi Sulawesi Barat yang berada di urutan kedua tertinggi setelah Provinsi Nusa Tenggara Timur.

Di provinsi Sulawesi Barat, tercatat prevalensi status gizi balita stunting berdasarkan TB/U (Tinggi Badan menurut umur) sebesar $48,0 \%$ terdiri dari sangat pendek dan pendek masing-masing adalah 22,3\% dan 25,7\%. Adapun prevalensi balita sangat pendek dan pendek di 5 kabupaten di Sulawesi Barat yang pertama ialah Kabupaten Majene dengan 58,6\%, lalu Kabupaten Polewali Mandar dengan 48,5\%, disusul Mamuju Utara 47,8\%, Mamuju 47,3\% dan Mamasa sebanyak $37,6 \%$.

Sementara itu data Kementerian Kesehatan tahun 2017 mengatakan angka stunting di Provinsi Suklawesi Barat telah mencapai $40 \%$ yang artinya sejak tahun 2013 hingga 2017 telah terjadi penurunan angka stunting. Namun bagaimanapun, stunting masih tetap menjadi tantangan besar bagi tenaga kesehatan di Sulawesi Barat bahkan di indonesia, mengetahui jika $40 \%$ angka stunting itu tergolong masih cukup besar.menurut laporan Gizi Kabupaten Polewali Mandar tahun 2017, jumlah anak dengan status gizi stunting sebanyak 1343 anak dari total 4834 anak atau sekitar 27,78\%. Adapun wilayah dengan status gizi stunting tertinggi di Polewali Mandar ialah puskesmas 
tinambung dengan 1511 anak (44,02\%), kemudian puskesmas pambusuang dengan 122 anak $(40,67 \%)$ yang dilaporkan telah mengalami penurunan angka stunting dari sebelumnya $(48,3 \%)$ di tahun 2016, kemudian diurutkan ketiga ialah Puskesmas Bulo dengan 120 anak (40\%) yang juga dilaporkan telah mengalami penurunan angka stunting yang sebelumnya sebanyak (52\%), dan diurutkan ke empat ialah Puskesmas Mapilli dengan 104 anak (34,67\%).Selanjut nya Puskesmas Wonomulyo dengan 307 anak balta ..

Adapun berdasarkan data petugas sanitasi puskesmas Wonomulyo laporan JanuariOktober 2018 dengan indikator Sarana buang air limbah (SPALtertarik) capainya 75\% ketersedian Jamban 85\% Sarana Air Bersih $37,1 \%$ dan data penyakit diare (penyakit infeksi) 4,3\% . Data dari Puskesmas Wonomulyo Januari sampai dengan september 2018 penderita diare 458 orang (jiwa).

Kondisi sanitasi yang buruk umunya prevelensi stunting tinggi. Dari uraian latar belakang diatas peneliti tertarik untuk melakukan penelitian tentang Hubungan Sanitasi Lingkungan Rumah Tangga Dengan Kejadian Stunting Pada Anak Balita Di Puskesmas
Wonomulyo kecamatan Wonomulyo Kabupaten Polewali Mandar Sulawesi Barat.

\section{BAHAN DAN METODE}

Jenis penelitian yang di gunakan adalah analitik Kuantitatif dengan desain penelitian case control. Analitik observasional adalah penelitian yang menjelaskan adanya pengaruh antara variabel-variabel yang akan diteliti melalui pengujian hipotesis yang telah dirumuskan terlebih dahulu (Suryabrata,1989 dalam indah ,2011).

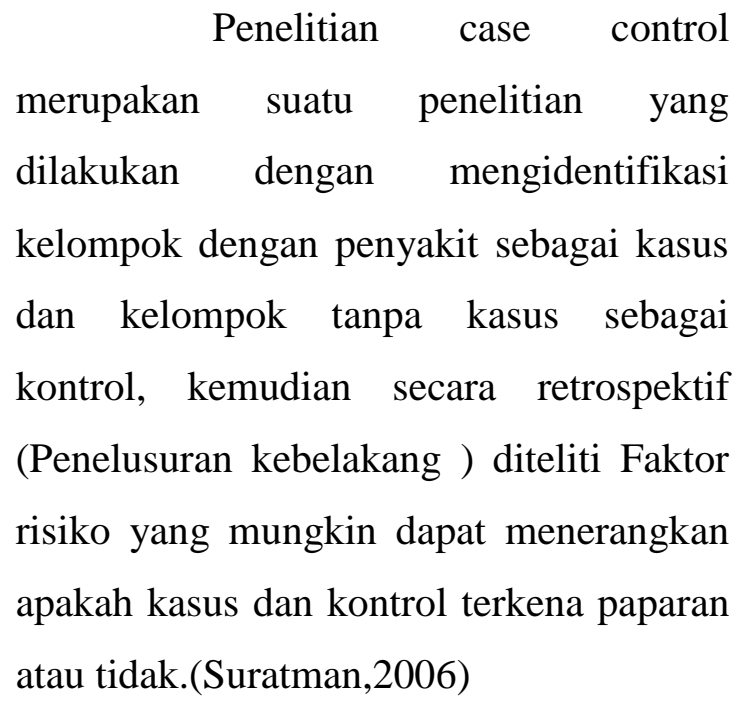
Penelitian case control (1) (a) (n) 
Hasil dan Pembahasan

\section{GambaraUmum}

Kabupaten Polewali Mandar yang beribu kota di terletak di antara 3 4'10"3 32'00” lintang selatan dan 118 40'27'119 29'41" bujur timur. Kabupaten mandar bagian utara berbatasan dengan kabupaten Mamasa, bagian timur dengan kabupaten Pinrang sebelah selatan dengan teluk mandar dan selat Makassar. Luas wilayah kabupaten mandar $2.022 .30 \mathrm{~km}^{2}$ yang meliputi 16 ( enam belas) kecamatan Tofografi wilayah kabupaten mandar terdiri atas dataran tinggi, rendah dan pesisir

pantai termasuk juga daerah sekitar aliran sungai besar mandar dan Maloso.
Sarana pelayanan kesehatan masyarakat di kabupaten mandar terdiri dari 16 puskesmas perawatan dan 4 puskesmas non perawatan dengan jumlah puskesmas pembatu ( pustu ) sebanyak 56 pustu dan 97 pondok bersalin desa/poskesdes dan 1 RSUD mandar 2klinik khusus, 3 klinit swasta. Tenaga kesehatan yang ada di kabupaten mandar terdiri dari 26 dokter umum, 20 dokter ahli, 13 dokter pengawai tidak tetap (PTT), 330 bidan, 209 perawat 19 petugas gizi. Sanitasi 25 orang, apoteker 12 orang, sarjana kesehatan masyarakat 51 orang Dinkes polman, 2016).

\section{Analisis Bivariate}

a. Faktor risiko mecuci tangan di air mengalir menggunakan sabun terhadap kerjadin stunting pada balita.

Tabel 1. Hasil analisis berdasarkan variabel mencuci tangan di ari mengalir menggunakan sabun

\begin{tabular}{cccccc}
\hline $\begin{array}{c}\text { No. } \\
\begin{array}{c}\text { Mencuci tangan } \\
\text { di air mengalir } \\
\text { menggunakan } \\
\text { sabun }\end{array}\end{array}$ & Kasus & $\begin{array}{c}\text { Stunting pada balita } \\
\text { Persentase }\end{array}$ & P value \\
\hline & 23 & 41.8 & 0 & 0 & 0.000 \\
Tidak & 32 & 58.2 & 55 & 100 & \\
Ya & 55 & 100,0 & 55 & 100,0 & \\
Total & &
\end{tabular}

Sumber : Data Primer 2019 
Berdasarkan tabel 1 menunjukkan bahwa pada kelompok kasus dari 23 responden yang tidak mencuci tangan dengan sabun, terdapat 23 orang $(41,8 \%)$ mengalami stunting dan tidak mengalami stunting atau (0\%) pada kelompok kontrol. Sedangkan dari 87 responden yang mencuci tangan dengan sabun terdapat 32 orang $(58,2 \%)$ mengalami stunting pada kelompok kasus dan terdapat 55 orang (100\%) mengalami stunting pada kelompok kontrol.
Berdasarkan hasil statistik dengan uji odds rasio di peroleh nilai OR 2,719 dimana cuci tangan di air mengalir pakai sabun terhadap kejadian stunting dengan tingkat kepercayaan (CI) $95 \%$ yaitu (2.064- 3.581) . Karena nilai lower limit tidak mencakup nilai 1 dan di dukung oleh nilai $\mathrm{p}$ value sebesar $0.000(0.000>0,05)$ maka secara statistik dikatakan bermakna sehingga penelitian ini menunjukkan adanya pengaruh yang bermakna antara cuci tangan di air mengalir pakai sabun terhadap kejadian stunting.

b. Pengamanan sampah rumah tangga

Tabel 1. Hasil analisis berdasarkan pengamanan sampah rumah tangga terhadap kejadian stunting pada balita

\begin{tabular}{|c|c|c|c|c|c|c|}
\hline \multirow{2}{*}{\multicolumn{2}{|c|}{$\begin{array}{r}\text { No. Pengamanasamp } \\
\text { ah rumah tangga }\end{array}$}} & \multicolumn{4}{|c|}{$\begin{array}{c}\text { Stunting pada balita } \\
\text { Persentase }\end{array}$} & \multirow[t]{2}{*}{$\mathrm{P}$ value } \\
\hline & & Kasus & $\%$ & Kontrol & $\%$ & \\
\hline & Tidak & 22 & 40.0 & 0 & 0 & 0.000 \\
\hline & Ya & 33 & 60,0 & 55 & 100 & \\
\hline & Total & 55 & 100,0 & 55 & 100,0 & \\
\hline
\end{tabular}

Sumber : Data Primer 2019

Berdasarkan hasil statistik di dikatakan bermakna sehingga peneitian ini peroleh data faktor risiko pengamaan menunjukkan adanya pengaruh yang sampah rumahvalue sebesar 0.000 bermakna antara pengamanan sampah $(0.000>0.05)$ maka secara statistik rumah tangga terhadap kejadian stunting 
c. Pengelolaanair minum dan makanan terhadap kejadian stunting pada balita

Tabel 1. Hasil analisis berdasarkan pengamanan sampah rumah tangga terhadap kejadian stunting pada balita

\begin{tabular}{cccccc}
\hline No. $\begin{array}{c}\text { Pengamanan } \\
\text { sampah rumah } \\
\text { tangga }\end{array}$ & Kasus & $\%$ & Kontrol & $\%$ & P value \\
Persentase & & \\
\hline Tidak & 1 & 1,8 & 0 & 0 & 1.000 \\
Ya & 44 & 98,2 & 55 & 100 & \\
Total & 55 & 100,0 & 55 & 100,0 & \\
\hline
\end{tabular}

Sumber : Data Primer 2019

Menjelaskan bahwa terdapat 1

kontrol melakukan pengelolan air minum $(1,8 \%)$ responden pada kelompok kasus dan makan rumah tangga . Berdasarkan yang tidak melakukan pengelolaan air hasil statistik dengan nilai $p$ velue sebesar minum dan makanan rumah tangga $1.000(1.000>0.05)$ sehingga penelitian ,kemudian terdapat $54(98,2 \%)$ responden ini tidak mempunyai pengaruh yang kelompok kasus yang melakukan bermakna antara pengelolaan air minum pengelolaanair munum dan makan rumah tangga dan 55 (100\%) pada kelompok dan makanan rumah tangga terhadap kejadian stunting.

d. Pengamana saluran pembuangan air limbah rumah tangga terhadapkejadian stunting pada balita

\begin{tabular}{|c|c|c|c|c|c|c|}
\hline \multirow[t]{5}{*}{ No. } & \multirow{2}{*}{$\begin{array}{l}\text { Pengamanan } \\
\text { saluran } \\
\text { pebuangan air } \\
\text { limbah }\end{array}$} & \multicolumn{4}{|c|}{$\begin{array}{c}\text { Stunting pada balita } \\
\text { Persentase }\end{array}$} & \multirow[t]{2}{*}{$\mathrm{P}$ value } \\
\hline & & Kasus & $\%$ & Kontrol & $\%$ & \\
\hline & Tidak & 11 & 1,8 & 0 & 0 & 0.000 \\
\hline & Ya & 44 & 98,2 & 55 & 100 & \\
\hline & Total & 55 & 100,0 & 55 & 100,0 & \\
\hline
\end{tabular}

Sumber: data Primer 2019

terdapat $11(20 \%)$ responden pada

kelompok kasus yang tidak melakukan pengamanan saluran pembuangan air limbah rumah tangga ,kemudian terdapat
$44(80 \%)$ responden pada kelompok kasus yang melakukan pengamana saluran pembuangan air limbah rumah tangga dan $55(100 \%)$ pada kelompok kontrol yang 
melakukan pengamanan saluran pembuangan air limbah rumah tangga.

Berdasarkan hasil statistik dengan $\mathrm{p}$ value sebesar $0.000(0.000>0.005)$ maka secara statistik dikatakan bermakna

\section{PEMBAHASAN}

Hasil penelitian menunjukkan bahwa pada kelompok kasus dari 23 responden yang tidak mencuci tangan dengan sabun, terdapat 23 orang $(41,8 \%)$ mengalami stunting dan tidak mengalami stunting atau (0\%) pada kelompok kontrol. Sedangkan dari 87 responden yang mencuci tangan dengan sabun terdapat 32 orang $(58,2 \%)$ mengalami stunting pada kelompok kasus dan terdapat 55 orang $(100 \%)$ mengalami stunting pada kelompok kontrol.

Sejalanan dengan hasil penelitian Fahmi Hafid dkk (2016) Kejadian Stunting pada usia 6-23 bulan memiliki hubungan yang signifikan dengan mencuci tangan menggunakan sabun $(\mathrm{p}<0,005)$.Hasil yang sejalan di perlihatkan pula oleh Peneliti Rahma yang menunjukkan bahwa kebiasaan ibu atau pengasuh anak mencuci tangan dengan sabun sebelum memberi makan atau setelah buang air besar terkait dengan penurunan $15 \%$ risiko stunting. sehingga penelitian ini menunjukkan adanya pengaruh yang bermakna antara pengamanan saluran pembuangan air limbah rumah tangga terhadap kejadian stunting.

Cuci tangan di air mengalir pakai sabun bukan saja dari anak yang sudah mengenal sesuatau atau dengan kata lain anak sudah menggunakan motorik halus dan kasar . disini peran seorang ibu pentingnya berpengetahuan terhadap kehidupan 1000 hari dalam kehidupannya manusia di dunia memperhatikan kondisi tempat tinggal ,dan sanitasi lingkungan yang baik yang tidak akan menjadikan pertumbuhan dan perkembangan nya terhambat.

Pengamanan sampah rumah tangga adalah melakukan kegiatan pengolahan sampah di rumah tangga dengan mengedepankan prinsip menggurangi,memakai ulang, dan mendaur ulang. Tinjauan pengaman sampah rumah tangga adalah untuk menghindari penyimpanan sampah yang aman adalah pengumpulan, pengangkutan, pemerosesan, pendaur ulangan atau pembuangan dari material sampah dengan cara yang membahayakan kesehatan masyarakat dan lingkungan. Hasil 
Penelitian sejalan yang dilakukan wulandari dkk tahun2018 ada hubungan sanitasi lingkungan dengan kejadian stunting di wilayah kerja puskesmas kerkep kabupaten bengkulu utara dengan nilai $\mathrm{p}=0.008$.Sulitnya akses santasi dan sanitasi yang buruk memicu Stunting pada anak ( kemen desa PDDT 2017.

Hasil Penelitian menunjukkan bahwa pada kelompok kasus dari 22 responden yang tidak menggunakan pengamanan sampah rumah tangga, terdapat 22 orang (100\%) mengalami stunting dan tidak mengalami stunting atau (0\%) pada kelompok kontrol. Sedangkan dari 88 responden yang menggunakan pengamanan sampah rumah tangga, terdapat 33 orang $(60,0 \%)$ mengalami stunting pada kelompok kasus dan terdapat 55 orang (100\%) mengalami stunting pada kelompok kontrol.

Pengelolaan air minum dan makanan menunjukkan bahwa pada kelompok kasus dan kontrol dari 110 responden yang tidak melakukan pengelolaan makanan dan minuman hanya 1 orang $(1,8 \%)$ pada kelompok kasus mengalami stunting dan tidak terdapat stunting pada kelompok kontrol. Sedangkan dari 109 responden yang melakukan pengelolaan makanan dan minuman, terdapat 54 orang $(98,2 \%)$ mengalami stunting pada kelompok kasus dan terdapat 55 orang (100\%) mengalami stunting pada kelompok kontrol.

Hasil penelitian ini sejalan dengan Wanda lestari dkk 2014 Anak stunting sebagian besar terjadi anak pendapatkan pola asuh yang kurang baik dalam praktek pemberian makanan $(\mathrm{OR}=4,59 \%$ $\mathrm{p}=0,0001$ ) hasil penelitian ini menunjukkan bahwa pola asuh yang kurang baik merupakan faktor risiko stunting pada anak umur 6-24 bulan.Pengelolaan air minum dan makanan di lakukan untuk mendapatkan air dengan kualitas . Air minum , air yang sudah diolah menjadi air minum yang di gunakan dan di komsumsi secara rutin setiap hari dan disimpan dalam wadah tertutup agar terhindar dari permasalahan penyakit di karenakan air yang tidak di olah dan tidak di amankan begitu pula halnya dengan makan yang sudah di masak dan disajikan selalu tertutup dan wadah yang di gunakan selalu bersih menurut dep kes RI 2003 , dalam menyimpan makan jadi harus memperhatikan suhu dan kelembaban sesuai dengan persyaratan jenis makanan dan cara penyimpanan nya. 


\section{KESIMPULAN}

Berdasarkan hasil penelitian analisis hubungan sanitasi lingkungan rumah tangga dengan kejadian stunting pada balita di Wilayah Kerja Puskesmas Kecamatan Wonomulyo yang telah dilakukan maka dapat di simpulkan

1. Responden yang tidak cuci tangan di air mengalir pakai sabun di wilayah kerja Puskesmas Wonomulyo Kabupaten Polewali Mandar 2,719 kali beresiko mengalami stunting dari pada responden yang mencuci tangan pakai sabun di air mengalir.

2. Respoden yang tidak melakukan pengamanan sampah rumah tangga di wilayah kerja Puskesmas Wonomulyo Kabupaten Polewali Mandar 2,667 kali beresiko mengalami stunting dari pada responden yang melakukan pengamanan sampah rumah tangga.

3. Responden yang tidak melakukan pengelolaan air minum dan makanan di wilayah kerja Puskesmas Wonomulyo Kabupaten Polewali Mandar 2,019 kali beresiko mengalami stunting dari pada responden yang melakukan pengelolaan air minum dan makanan rumah tangga.

4. Responden yang tidak melakukan pengamanan saluran pembuangan air limbah diwilayah kerja Puskesmas
Wonomulyo Kabupaten Polewali Mandar 2.250 kali beresiko mengalami stunting dari pada responden yang melakukan pengamanan saluran pembuangan air limbah rumah tangga

\section{UCAPAN TERIMA KASIH}

Rektor Universita Al Asyariah Mandar, Dekan Fakultas Kesehatan Masyarakat, Dinas Kesehatan Kabupaten Polewali Mandar, Pukesmas Kecamatan Wonomulyo, Bidan dan kader Posyandu se-kecamatan Wonomulyo, adinda k tersayang patmawati serta kedua anak ku tercinta yaitu Deta dan Agil yang selalu mendampingi ibu menyelesaikan Tugas Akhir.

\section{DAFTAR RUJUKAN}

1. Alien \& Sillespie (2001),Takdir risiko meningkatnya angka kematian

2. Candra Budiman (2012) (kesehatan lingkungan) pengelola air minum

3. Buletin Jendela Data dan Informasi Kesehatan. ISSN 2088-270 X. Semester I, 2008. Topik Utama Situasi balita Pendek (syunting) di Indonesia. Pusat data dan informasi, Kementerian Kesehatan RI. 
4. Dinas kesehatan Kabupaten Polewali Mandar Profil Kesehatan Masyarakat Kabupaten Polewali Mandar 20172018

5. Gibson 2005. Pengukuran Antropometri protein dan energy Jhont child motnutation etimotes (2018) - 2kes.

6. Gambar 5. Kerangka pembahasan pendek (stunting) di Indonesia, dimodifikasi dari "Logical framework of the Nutritional Problems" Unicef, 2013.( Pendek Stunting di Indonesia masalah dan solusinya oleh Trihono Atmarita).

7. Keputusan Menteri Kesehatan Republik Indonesia. Nomor: 1995/Menkes/SK/XII/2010. Tentang standar antropometri penilaian status gizi. Direktorat jenderal bina gizi kesehatan ibu dan anak. Direktorat Gina Gizi. 2011.

8. Potter \& perry 2005) jurnal sanitasi dan kesehatan lingkungan Puskesmas Anreapi, Profil Puskesmas Wonomulyo2017-2018

9. Soekirman, Afriansyah N, ErikaniaJ. "Gizi seimbang untuk anak usia0-2 tahun.” Dalam: Sehat \& BugarBerkat Gizi Seimbang. Jakarta:Nakita
Kompas-Gramedia \& InstitutDanone Indonesia, 2010.

10. Siswanto, 2009 Pentingnya mencuci tangan (notoatmojo, 2012) pengertian populasi (Lemeshow, 1999) Pengambilan Sampel

11. Musadad DA, Hananto M. Tingkat risiko sarana air minum dikabupaten Sukabumi. Jurnal Ekologi Kesehatan 2008; 7(3): 819-28.

12. Musadad DA, Irianto J. Pengaruh penyediaan air minum terhadap kejadian karies gigi usia 12-65 tahundi Provinsi Kep. Bangka Belitungdan Nusa Tenggara Barat. Jurnal Ekologi Kesehatan 2009; 8(3):1032-46.

13. Notoatmodjo Soekidj. Ilmu Kesehatan masyarakat (prinsipprinsip Dasar). Rineke Cipta. Jakarta. Mei, 2003

14. Notoatmojo, Soekidjo. (2005). Metodologi Penelitian Kesehatan.Jakarta : PT Rineka Cipta.

15. Wordl Health Organization (WHO). 2014. WHA Global Nutrition Targets 2025. Stunting Policy Brief.

16. Keputusan Menteri Kesehatan Republik Indonesia, Nomor: 1995/MENKES/SK/XII/2010 tentang Standar Antropomentri Penilaian 
Jurnal Kesehatan Masyarakat, Vol. 5, No.2, Nov 2019

Status Gizi Anak. Kementerian

Kesehatan RI. Direktorat Jenderal
p-ISSN: 2442-8884 / e-ISSN: 2541-4542

Bina Gizi dan Kesehatan Ibu dan Anak Direktorat Bina Gizi 2011. 